\title{
Generation of $\mathrm{CD2}^{+} \mathrm{CD}^{+} \mathrm{NK}^{+}$Cells from c-Kit ${ }^{+}$Bone Marrow Cells in Porcine
}

Kyu Hee Lim', Ji-Hui Han', Yoon Seok Roh ${ }^{2}$, Bumseok Kim ${ }^{2}$, Jung-Kee Kwon ${ }^{3}$, Myoung Jo You ${ }^{4}$ Ho Jae $\mathrm{Han}^{5}$, Sohail Ejaz ${ }^{6}$, Chang-Won Kang', and Jong-Hoon Kim ${ }^{1}$

${ }^{1}$ Department of Physiology and Biosafety Research Institute, College of Veterinary Medicine, Chonbuk National University, Jeonju 561-756, Departments of ${ }^{2}$ Pathology, ${ }^{3}$ Laboratroy Animal Medicine, ${ }^{4}$ Parasitology, College of Veterinary Medicine, Chonbuk National University, Jeonju 561-756, ${ }^{5}$ Department of Veterinary Physiology, College of Veterinary Medicine, Seoul National University, Seoul 151-741, Korea, ${ }^{6}$ Department of Clinical Neurosciences, Neurology Unit, Addenbrooke's Hospital, University of Cambridge, Cambridge CB2 0QQ, UK

\begin{abstract}
Natural killer (NK) cells provide one of the initial barriers of cellular host defense against pathogens, in particular intracellular pathogens. Because bone marrow-derived hematopoietic stem cells (HSCs), lymphoid protenitors, can give rise to NK cells, NK ontogeny has been considered to be exclusively lymphoid. Here, we show that porcine c-kit ${ }^{+}$bone marrow cells (c-kit ${ }^{+}$BM cells) develop into $\mathrm{NK}$ cells in vitro in the presence of various cytokines [interleukin (IL)-2, IL-7, IL-15, IL-21, stem cell factor (SCF), and fms-like tyrosine kinase-3 ligand (FLT3L)]. Adding hydrocortisone (HDC) and stromal cells

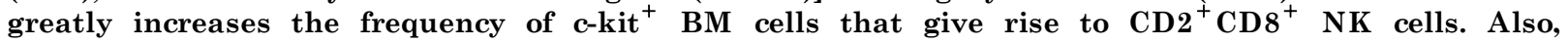
intracellular levels of perforin, granzyme B, and NKG2D were determined by RT-PCR and western blotting analysis. It was found that of perforin, granzyme B, and NKG2D levels significantly were increased in cytokine-stimulated c-kit ${ }^{+} \mathrm{BM}$ cells than those of controls. And, we compared the ability of the cytotoxicity of $\mathrm{CD2}^{+} \mathrm{CD}^{+} \mathrm{NK}$ cells differentiated by cytokines from c-kit ${ }^{+} \mathrm{BM}$ cells against K562 target cells for 28 days. Cytokines-induced NK cells as effector cells were incubated with K562 cells as target in a ratio of $100: 1$ for $4 \mathrm{~h}$ once a week. In results, $\mathrm{CD2}^{+} \mathrm{CD}^{+} \mathrm{NK}$ cells induced by cytokines and stromal cells showed a significantly increased cytotoxicity 21 days later. Whereas, our results indicated that c-kit ${ }^{+}$BM cells not pretreated with cytokines have lower levels of cytotoxicity. Taken together, this study suggests that cytokines-induced NK cells from porcine c-kit ${ }^{+}$BM cells may be used as adoptive transfer therapy if the known obstacles to xenografting (e.g. immune and non-immune problems) were overcome in the future.
\end{abstract}

Key Words: Hematopoietic stem cells, Natural killer cells, Differentiation, Cytokines, Cytotoxicity

\section{INTRODUCTION}

The porcine is a useful animal model for biomedical research in xeno-transplantation as well as in regenerative medicine. Organ size and physiological similarities between humans and porcine make these animals suitable organ transplantation for humans [1,2]. However, organ transplantation across species is prone to vigorous immunologic rejection. Transplantation of whole bone marrow (BM) cells or selected subsets has been a successful strategy to achieve chimerism and induction of tolerance in different xeno-

Received February 6, 2012, Revised April 17, 2012,

Accepted April 17, 2012

Corresponding to: Jong-Hoon Kim, Department of Physiology, College of Veterinary Medicine, Chonbuk National University, 664-14, Duckjin-dong, Jeonju 561-756, Korea. (Tel) 82-63-270-2563, (Fax) 82-63-270-3780, (E-mail) jhkim1@chonbuk.ac.kr (1) (2) This is an Open Access article distributed under the terms of the
Creative Commons Attribution Non-Commercial License (http:// Creative Commons Attribution Non-Commercial License (http:/ use, distribution, and reproduction in any medium, provided the original work is properly cited. transplantation studies [3,4]. Nevertheless, in spite of promising results, this approach remains limited in part because certain BM cell subpopulations may cause graft-versus-host disease (GVHD).

BM-derived stem cells are the most primitive cells that establish a fully self-renewing population and retain multilineage hematopoietic differentiation potential. Unlike whole $\mathrm{BM}$, stem cell-enriched populations do not contain mature lymphocytes capable of inducing GVHD. In the adult BM, most hematopoietic progenitors express c-kit (CD117), a member of a family of cell-surface receptors with tyrosine kinase activity. Purified c-kit ${ }^{+} \mathrm{BM}$ cells have been used in mice to induce stable multilineage mixed chimerism and permanent acceptance of donorspecific grafts without any clinical signs of GVHD [3]. Human hematopoietic stem cells (HSCs) with long term engrafting abilities are also almost

ABBREVIATIONS: GVHD, graft-versus-host disease; BM, bone marrow; HSCs, hematopoietic stem cells; NK, natural killer; SCF, stem cell factor; IL, interleukin; FLT3L, fms-like tyrosine kinase-3 ligand; HDC, hydrocortisone; FCS, fetal calf serum; DMEM, Dulbecco's modified eagles medium; FITC, fluorescein isothiocyanate; PE, phycoerythrin; HUVECs, human umbilical vein endothelial cells; $\mathrm{SPF}$, specific pathogen-free. 
exclusively in the c-kit ${ }^{+}$population of $\mathrm{CD} 34^{+} \mathrm{BM}$ cells [5]. On the other hand, the recent demonstration of the capacity of BM-derived HSCs to differentiate into nonhematopoietic lineages such as hepatocytes, skeletal muscle cells, neurons or epithelial cells of the lung, gastrointestinal tract and skin, has raised hopes as to their therapeutic potential in regenerative medicine [6].

Natural killer (NK) cells are innate immune effector cells. Their derivation from either lymphoid or myeloid lineages was debated early in their discovery [7]. Further research showed that NK cells can be derived from common lymphoid progenitors and hence have been considered separate from myeloid lineage $[8,9]$. However, some studies question this and have shown that progenitors expressing myeloid antigens can develop into NK cells $[10,11]$. In previous study, it is shown that NK cell differentiation from HSCs can be studied in vitro $[12,13]$. This process depends on cytokines, notably interleukin-2 (IL-2) or IL-15, whereas other factors (stem cell factor [SCF], fms-like tyrosine kinase-3 ligand [FLT3L]) induce early HSCs expansion and responsiveness to IL-2 and IL-15 signaling [14]. To date, the factors regulating NK differentiation from porcine c-kit ${ }^{+} \mathrm{BM}$ cells are poorly understood. However, it is certain that it involves cell to cell interactions that render NK responsive to soluble factors from the microenvironment, and several factors such as IL-15 are reported to be involved in differentiation of NK cells from HSCs [15]. Although the intact BM microenvironment is essential for NK differentiation, the some cytokines might be required by early acting including SCF, FLT3L, and IL-7 $[16,17]$ in porcine as did differentiation to NK cells from human HSCs. In the present report, we investigated the role of a various of cytokines in the development of $\mathrm{CD} 2{ }^{+} \mathrm{CD} 8^{+} \mathrm{NK}$ cells from porcine c-kit ${ }^{+}$ $\mathrm{BM}$ cells, and analyzed the cytotoxic activities of $\mathrm{CD} 2^{+} \mathrm{CD} 8^{+}$ NK cells.

Until recently, it is well known that NK cells are effective at clearing tumors of epithelial origin as well as metastases from tumors [18]. Grzywacz et al. showed that human myeloid precursors, hematopoietic stem cells, can differentiate into NK cells and the NK cells can kill humanerythroleukemic cells [19]. Moreover, it is reported that NK cells exhibit spontaneous cytotoxicity against MHC class I-deficient target cells, and they participate in the innate immune responses against transformed cells and tumor metastases in vivo [20]. In addition, it is studied that the porcine NK cells after cytokine stimulation lysis humanerythroleukemic cells [21]. Particularly, Sotiriadis et al. reported that porcine NK cells can lysis human carcinoma cells [22].

As mentioned above, the concept that NK cells can be derived from the c-kit ${ }^{+} \mathrm{BM}$ cells advances our understanding of the NK ontogeny and relationship to other blood lineages, creating the potential for therapeutic applications.

\section{METHODS}

\section{Animals}

We used 15 male porcines (10 12 weeks old, $20 \sim 25 \mathrm{~kg}$ ) purchased from Samtako (South Korea). An automatically controlled $12 \mathrm{~h}$ photoperiod (lights on 07:00 a.m. and off 07:00 p.m.) and thermostatically regulated ambient temperature $\left(20 \sim 21^{\circ} \mathrm{C}\right)$ were maintained throughout the experiment. The porcines were housed individually in stainless steel crates, fed the standard, completely balanced pelleted dry food twice a day (07:00 07:30 a.m. and 02:00 02:30 p.m.), with water available ad libitum. The animals were acclimated to their new environment for about 1 week before the experiments. All efforts were made to minimize animal suffering and to reduce the number of animals used, with all the protocols being reviewed and approved by the Animal Research Ethics Committee of the Chonbuk National University (Jeonju, Korea) for the protection of vertebrate animals used for experimental and other scientific purpose.

\section{Purification of porcine c-kit ${ }^{+}$BM cells}

Porcines were euthanized and processed into a single cell suspension. Porcine bone marrow cells, containing c-kit ${ }^{+}$ HSCs, were harvested and isolated by a modification of the technique described previously [23]. Femurs were removed and cleaned of muscle tissue. Femurs were then dissected longitudinally and compressed to excise BM cells. BM cells were collected, washed with Dulbecco's modified Eagles medium (DMEM) containing 1\% (v/v) fetal calf serum (FCS) and $5 \mathrm{U} / \mathrm{ml}$ heparin, and processed into a single cell suspension. Since then, each sample was diluted in $0.9 \%$ sterile saline solution $(1: 1)(\mathrm{v} / \mathrm{v})$. After dilution was completed, the mixture was added to Ficoll-Paque PLUS $(1.077 \mathrm{~g} / \mathrm{ml}$; \#07907, StemCell Technologies, Vancouver, Canada) in another sterile tube and centrifuged at $400 \mathrm{~g}$ for $30 \mathrm{~min}$ at room temperature. Using a sterile Pasteur pipette the plasma layer on top was removed and discarded; care being taken to prevent any disturbance of the mononuclear cell layer. And, the aspirate of porcine mononuclear cell layer was collected and transferred into a sterile $17 \times 100 \mathrm{~mm}$ polystyrene tube. Ammonium chloride lysis was performed on the remaining pellet to remove red blood cells. Once completely lysed, the pellet was three times with $15 \mathrm{ml}$ of McCoy's $5 \mathrm{~A}$ culture media, and centrifuged at $400 \mathrm{~g}$ for $5 \mathrm{~min}$ each time. A cell count was then performed using an automatic cell counter in order to determine the number of nucleated cells in the culture plate. Routine microbiologic monitoring did not reveal any evidence of infection with common pathogens.

\section{Isolation of porcine c-kit ${ }^{+} \mathrm{BM}$ cells}

For isolation of c-kit ${ }^{+} \mathrm{BM}$ cells from mononuclear cells, biotinylated porcine SCF was used to detect and purify porcine c-kit ${ }^{+}$cells [24]. Briefly, low-density cells separated with Histopaque (Sigma, St. Louis, MO, USA) were incubated for $1 \mathrm{~h}$ on ice with biotinylated SCF $\left(320 \mu \mathrm{g} / 1 \times 10^{9} \mathrm{BMCs}\right.$ for magnetic bead separation), and then stained for $15 \mathrm{~min}$ with streptavidin-coated magnetic microbeads (Miltenyi Biotec, Bergisch-Gladbach, Germany). After extensive phosphate-buffered saline (PBS) washes, c-kit ${ }^{+}$cells were sorted by the MACS system (Miltenyi Biotec). Percentages of c-kit ${ }^{+}$ cells fractions used in this study were greater than $95 \%$.

\section{Developments of cytokines-induced $\mathrm{CD}^{+} \mathrm{CD}^{+} \mathrm{NK}$ cells from porcine c-kit ${ }^{+} \mathrm{BM}$ cells}

The human umbilical vein endothelial cells (HUVECs) was cultured to confluence and was irradiated (30 Gy [3000 rad]) [25]. Porcine c-kit ${ }^{+}$BM cells were cultured with a monolayer of HUVECs plus Dulbecco modified Eagle medium (DMEM) (1:2 ratio) with $20 \%$ porcine serum, ethanolamine $(50 \mu \mathrm{M})$, ascorbic acid $(20 \mathrm{mg} / \mathrm{l}), 5 \mu \mathrm{g} / \mathrm{l}$ sodium selenite $\left(\mathrm{Na}_{2} \mathrm{SeO}_{3}\right), \beta$-mercaptoethanol $(24 \mu \mathrm{M})$, and peni- 
cillin $(100 \mathrm{U} / \mathrm{ml}) /$ streptomycin $(100 \mathrm{U} / \mathrm{ml})$. At the start of cultures, IL-2 (30 ng/ml) , IL-7 (10 ng/ml), IL-15 (10 ng/ml), IL-21 $(30 \mathrm{ng} / \mathrm{ml})$, SCF $(30 \mathrm{ng} / \mathrm{ml})$, and FLT3L $(50 \mathrm{ng} / \mathrm{ml})$ (R\&D Systems, Minneapolis, MN, USA) were added. Cultures were refed weekly by $50 \%$ volume change of media, supplemented with the above-listed cytokines (except IL-3), with HDC. For 28 days culture, once a week cytokines-activated cells were harvested, counted, and analyzed.

\section{FACS analysis}

Phenotypes of the cytokines-induced NK cells were characterized by multi-color flow cytometry analysis (FACS Calibur with two lasers, Becton Dickinson) using combinations of the porcine antibodies to facilitate two color analysis. Cells were stained unfixed in 96 well round bottom microtitre plates (Sterilin, Cambridge, UK). In each case, cells were incubated on ice with the CD2-fluorescein isothiocyanate (FITC) and CD8-phycoerythrin (PE) mAbs for $20 \mathrm{~min}$, washed and further incubated on ice for another $20 \mathrm{~min}$ with fluorescent dye conjugated secondary antibody (either isotype specific FITC, Alexa 488, Phycoerythrin, Alexa 633 or Streptavidin-PERCP-Southern Biotechnology Association, Molecular Probes, BD Biosciences). The cells were diluted and washed with FACS diluent; PBS $\mathrm{pH} 7.4$ plus $0.6 \%$ bovine serum albumin, $0.1 \%$ sodium azide and $2 \%$ horse serum. After the external staining the cells were given one final wash and fixed by the addition of $50 \mathrm{ml}$ of FACS-fix $(450 \mathrm{ml}$ sterile distilled water plus $60 \mathrm{ml} \mathrm{10 \times} \mathrm{calcium} / \mathrm{mag}$ nesium free PBS pH 7.4 [Sigma] and $15 \mathrm{ml}$ formaldehyde solution [38\% (w/w); Analar]) diluted 1 in 4 with FACS diluent and placed on ice for $1 \mathrm{~h}$. The cells were then washed with FACS diluent and $50 \mathrm{ml}$ of permeabilization solution [FACS diluent plus $0.05 \%$ Tween 20 (Sigma)] added to every well. The plates were then sealed and carefully floated on a $37^{\circ} \mathrm{C}$ water bath for $15 \mathrm{~min}$. The seal was removed and the cells washed with FACS diluent to remove the detergent.

\section{Reverse transcription and real-time polymerase chain reaction}

Total RNA from cytokines-activated cells $\left(5 \times 10^{6}\right.$ cells $\left./ \mathrm{ml}\right)$ was prepared by adding TRIzol Reagent (Invitrogen, California, USA) according to the manufacturer's protocol [26]. The RNA solution was stored at $-70^{\circ} \mathrm{C}$ until used. Semiquantitative reverse transcriptase reactions were conducted using MuLV reverse transcriptase. One milligram of RNA was incubated with oligo-dT15 for $5 \mathrm{~min}$ at $70^{\circ} \mathrm{C}$ and then mixed with a $5 \times$ first-strand buffer, $10 \mathrm{mM}$ dNTPs, and $0.1 \mathrm{M}$ DTT. The reaction mixture was further incubated for $5 \mathrm{~min}$ at $37^{\circ} \mathrm{C}$ and for $60 \mathrm{~min}$ after the addition of $\mathrm{MuLV}$ reverse transcriptase $(2 \mathrm{U})$. Reactions were terminated after $10 \mathrm{~min}$ at $70^{\circ} \mathrm{C}$, and total RNA was depleted by adding RNase $\mathrm{H}$. The polymerase chain reaction (PCR) was conducted with the incubation mixture (2 $\mathrm{ml} \mathrm{cDNA}, 4 \mathrm{mM} 5$, and 3' primers, a $10 \times$ buffer [ $10 \mathrm{mM}$ Tris- $\mathrm{HCl}, \mathrm{pH} 8.3,50$ $\mathrm{mM} \mathrm{KCl}, 0.1 \%$ Triton X-100], $250 \mu \mathrm{M}$ of dNTP, $25 \mathrm{mM}$ of $\mathrm{MgCl}_{2}$, and 1 unit of Taq polymerase [Promega, Wisconsin, USA]). The following incubation conditions were used: a 30 sec denaturation time at $94^{\circ} \mathrm{C}$, an annealing time of $30 \mathrm{sec}$ at $55^{\circ} \mathrm{C}$, an extension time of $45 \mathrm{sec}$ at $72^{\circ} \mathrm{C}$, and a final extension of $5 \mathrm{~min}$ at $72^{\circ} \mathrm{C}$. For RT-PCR analysis, one microgram of RNA was submitted to reverse transcription with the Molony murine leukemia virus reverse transcriptase (Invitrogen, California, USA). Two microliters of cDNA obtained from each sample were submitted to a qPCR assay using the SYBR green Master mix method (Life technology, Applied Biosystem, California, USA) in the ABO sequence detection system, The primers (Bioneer, Daejeon, Korea) used in this experiment are indicated as following [perforin F 5' - CTG GCT CAC ACG AGG TGA TG - 3'; perforin R 5' - TCA GGT GAG GCA AGC ACT TG - 3'], [granzyme B F 5' - AAC ACC CAG CTG TGT GTA GG - 3'; granzyme B R 5' - TGA GAC TTT GGT GCA GGC TC - 3'] and [NKG2D F 5' -TCC TCC CAG CAT GGA GAT AAG GGA3'; NKG2D R 5' - GTT AGG TGA GAG GAT GGA ACC ATC TTC - 3'], designed from published porcine sequences [27]. Each PCR product signal was normalized relative to that of G3PDH obtained from the same RNA.

\section{Preparation of protein lysate and immunoblot analysis}

Lysates of cytokines-stimulated c-kit ${ }^{+} \mathrm{BM}$ cells were separated as previously described [28]. Briefly, cytokines-stimulated $\mathrm{CD} 2^{+} \mathrm{CD} 8^{+} \mathrm{NK}$ cells $\left(5 \times 10^{6}\right.$ cells $\left./ \mathrm{ml}\right)$ washed 3 times in cold phosphate-buffered saline with $1 \mathrm{mM}$ sodium orthovanadate and were lysed in lysis buffer $(20 \mathrm{mM}$ Tris- $\mathrm{HCl}$, $\mathrm{pH}$ 7.4, 2 mM EDTA, $2 \mathrm{mM}$ ethyleneglycotetraacetic acid, $50 \mathrm{mM} \beta$-glycerophosphate, $1 \mathrm{mM}$ sodium orthovanadate, $1 \mathrm{mM}$ dithiothreitol, $1 \%$ Triton X-100, 10\% glycerol, $10 \mu \mathrm{g} /$ $\mathrm{ml}$ aprotinin, $10 \mu \mathrm{g} / \mathrm{ml}$ pepstatin, $1 \mathrm{mM}$ benzimide, and 2 $\mathrm{mM}$ PMSF) for $30 \mathrm{~min}$ with rotation at $4^{\circ} \mathrm{C}$. The lysates were clarified by centrifugation at $16,000 \mathrm{~g}$ for $10 \mathrm{~min}$ at $4^{\circ} \mathrm{C}$ and stored at $-20^{\circ} \mathrm{C}$ until needed.

Then, whole cell lysates were analyzed by immunoblotting methods as reported previously [29]. Briefly, proteins were separated on $10 \%$ sodium dodecyl sulfate-polyacrylamide gels and were transferred by electroblotting to a polyvinylidenedifluoride membrane. Membranes were blocked for $60 \mathrm{~min}$ in Tris-buffered saline containing $3 \%$ bovine serum albumin, $20 \mathrm{mM} \mathrm{NaF}, 2 \mathrm{mM}$ EDTA, and $0.2 \%$ Tween 20 at room temperature. The membrane was incubated for 60 min with specific primary antibody $[1: 1,000$ for perforin (Mouse IgG2b; clone No: F-1), granzyme B (Mouse IgG1; clone No: 2C5) and NKG2D (Mouse IgG1; clone No: 1D11) and $1: 2,000$ for $\beta$-actin (Mouse IgG1; clone No: C-4)] at $4^{\circ} \mathrm{C}$, washed 3 times with the same buffer, and incubated for an additional $60 \mathrm{~min}$ with horseradish peroxidase conjugated secondary antibody. The total levels of perforin, granzyme $\mathrm{B}, \mathrm{NKG} 2 \mathrm{D}$, and $\beta$-actin were visualized by chemiluminescence using Supersignal West Dura Extended Duration Substrate (Pierce, Rockford, IL, USA), and the intensity of the immunoreactive bands was quantified using a densitometer (Sanyo, Tokyo, Japan). Experiments were performed independently five times.

\section{Cytotoxic assay of cytokines-induced porcine $\mathrm{CD2}{ }^{+} \mathrm{CD} 8^{+}$ NK cells}

The cytotoxicity of procine NK cells was quantified using a ${ }^{51} \mathrm{Cr}$-release assay according to the procedure described previously in [30]. Briefly, in the NK cytotoxicity assay, the cytokines-induced $\mathrm{CD} 2^{+} \mathrm{CD} 8^{+} \mathrm{NK}$ cells were used as the effector cells. The CD2 ${ }^{+} \mathrm{CD} 8^{+} \mathrm{NK}$ cells were incubated in $100-\mathrm{mm}$ culture dish containing $7 \mathrm{ml}$ of DMEM with $20 \%$ porcine serum. And, the erythroleukemic tumor cell line; K562 cells obtained from ATCC (American Type Culture Collection, Rockville, MD, USA) were used as targets, This line was maintained in a stationary suspension culture in complete medium: RPMI 1640 supplemented with $10 \%$ 
A.

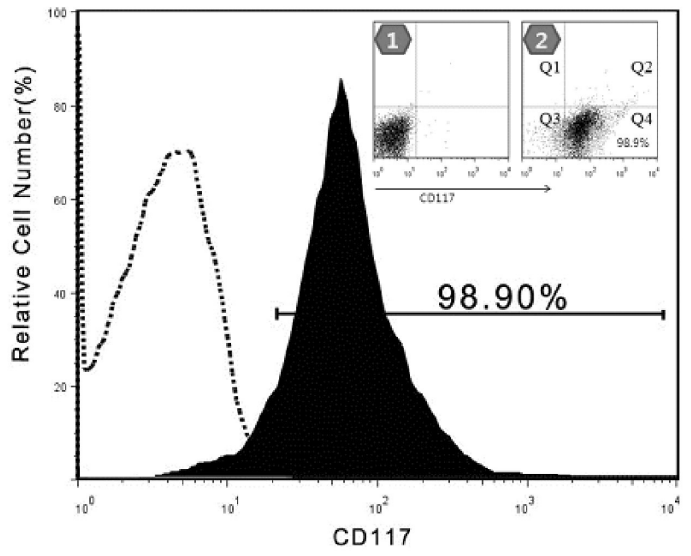

B.

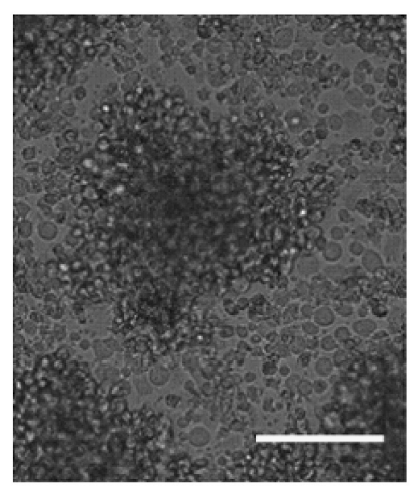

Fig. 1. Phenotyping of porcine bone marrow derived c-kit ${ }^{+}$cells. Porcine c-kit $^{+}$BM cells were isolated from bone marrow using a ficoll and magnetic activated cell sorter (MACS) and confirmed by fluorescence cell sorting (A). Histogram of isotype unstained control is shown (A: the part shown in dotted line area). Total number of $\mathrm{CD}_{117^{+}}$(c-kit $^{+}$) BM cells is shown (A: the part shown in black area). Panel 1; Respective isotype control in unstained c-kit ${ }^{+}$ $\mathrm{BM}$ cells gate is shown. Panel 2; Frequency of $\mathrm{CD} 17^{+}$cells after staining with monoclonal antibodies CD117-FITC is shown in Q4 region: (Q4=98.9\%). Porcine c-kit ${ }^{+}$cell colony obtained from porcine BM cells was photographed in stem cell medium (B, Bar: $50 \mu \mathrm{m}$ ). heat-inactivated fetal bovine serum (FBS) (Sigma, St Louis, USA), penicillin (Sigma, St Louis, USA) $(100 \mathrm{U} / \mathrm{ml})$ and streptomycin (Sigma, St Louis, USA) $(100 \mathrm{mg} / \mathrm{ml})$ in a $5 \%$ $\mathrm{CO}_{2}$ humidified incubator (standard culture conditions). Washed in complete medium, the K562 target cells $\left(5 \times 10^{6}\right)$ were labeled with $100 \mu \mathrm{Ci}$ of $\mathrm{Na}_{2}{ }^{51} \mathrm{CrO}_{4}$ (Radio Chemical Center, Otwock-Świerk, Poland) at $37^{\circ} \mathrm{C}$ for $1 \mathrm{~h}$. The labeled target cells were then washed five times using RPMI containing $2 \% \mathrm{FBS}$ and adjusted to $1 \times 10^{5} / \mathrm{ml}$ in complete medium The targets cells $\left(2 \times 10^{4}\right)$ were cultured in round-bottomed microwells plates (Nun, Roskilde, Denmark) with various concentrations of effector cells (effector: target cells ratios: $100: 1$ in a total volume of $200 \mu \mathrm{l}$ ) in triplicate, under standard culture conditions for $4 \mathrm{~h}$. Spontaneous ${ }^{51} \mathrm{Cr}$ release wells had target cells plus $100 \mu \mathrm{l}$ of complete medium and the maximum release wells contained target cells plus $100 \mu \mathrm{l}$ of complete medium with 5\% Triton X-100 (Sigma, St Louis, USA). The assay was terminated at the 4 th $\mathrm{h}$ by centrifuging the plates $(500 \times \mathrm{g}, 5 \mathrm{~min})$. Then 100 $\mu l$ of supernatant was removed from each well. An isotope count and the percentage of specific lysis (specific ${ }^{51} \mathrm{Cr}$ release) were performed with a gamma counter (Baker System 9120, Allentown, USA) as follows:

Specific ${ }^{51} \mathrm{Cr}$ release $=\frac{\text { Experimental }{ }^{51} \mathrm{Cr} \text { release }- \text { spontaneous }{ }^{51} \mathrm{Cr} \text { release }}{\text { Maximum }{ }^{51} \mathrm{Cr} \text { release }- \text { spontaneous }{ }^{51} \mathrm{Cr} \text { release }} \times 100$

\section{Statistical analysis}

All data were expressed as the mean \pm SD. Data were analyzed for statistical significance using one-way (ANOVA), followed by Tukey's test as a post-hoc test with SPSS software (SPSS for Windows, Version 10). A probability value of $\mathrm{p}<0.05$ was considered to indicate statistical significance, and all experiments were performed at least three times.

\section{RESULTS}

\section{Phenotype analysis of porcine c-kit ${ }^{+} \mathrm{BM}$ cells}

We examined the expression levels of porcine c-kit,

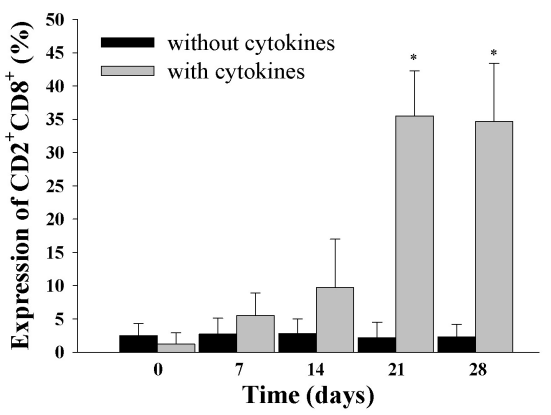

Fig. 2. Phenotypic analysis of $\mathrm{CD} 2{ }^{+} \mathrm{CD} 8^{+}$cells subpopulations in length of time for 28 days. There was a significant difference in expression of CD2 and CD8 molecules three weeks later from the treatment of cytokines compared to control $\left({ }^{*} \mathrm{p}<0.01\right)$.

CD117. The fluorescent intensity of Allexa Fluor 488-CD117 was used to measure the expression of c-kit. As shown in Fig. 1A, porcine BM cells were stained with more than $98.9 \pm 3.7 \%$ compare to isotype control. After $16 \mathrm{~h}, \mathrm{BM}$ cells were aggregated each other to clump (Fig. 1B).

\section{Cytokines-induced $\mathrm{NK}$ cells identified by $\mathrm{CD}^{+} \mathrm{CD} 8^{+}$ cells}

Surface marker CD2 and CD8 molecules are highly specific for porcine NK cells [31]. Cytokines-activated cells were isolated from co-culture plate with HUVEC. Then, $\mathrm{CD} 2{ }^{+} \mathrm{CD} 8^{+}$cells were determined using a FACS analysis. Only primary cultured cells were used, because they have the ability to become various types of cells under specific culture conditions. Therefore, cytokines-activated c-kit ${ }^{+}$ BM cells for $7^{\text {th }}, 14^{\text {th }}, 21^{\text {th }}$ and $28^{\text {th }}$ days were confirmed by FACS analysis using porcine NK cells marker-specific antibodies (Fig. 2, ${ }^{*} \mathrm{p}<0.01$ ). The FACS results demonstrate that $1.2 \pm 1.7,5.5 \pm 3.4,9.7 \pm 7.3,35.5 \pm 6.8$ and $34.7 \pm 8.7 \%$ of the cytokines-induced NK cells expressed CD2 and CD8 molecules compared to c-kit ${ }^{+} \mathrm{BM}$ cells not pretreated with cytokines $(2.5 \pm 1.8,2.7 \pm 2.4,2.8 \pm 2.2,2.2 \pm 2.3$ and $2.3 \pm 1.9 \%$, respectively) in length of time (Fig. $2,{ }^{*} p<0.01$ ). Whereas, all c-kit ${ }^{+} \mathrm{BM}$ cells did not differentiate to $\mathrm{CD} 2{ }^{+} \mathrm{CD} 8^{+} \mathrm{NK}$ 
A.

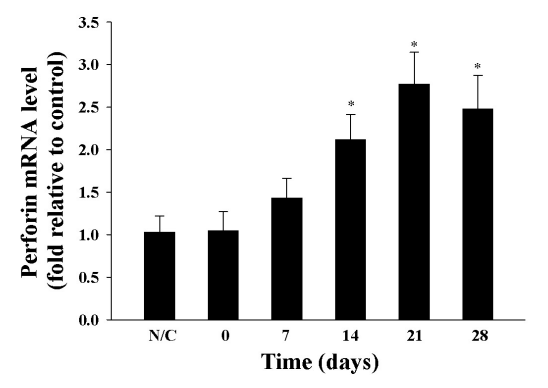

B.

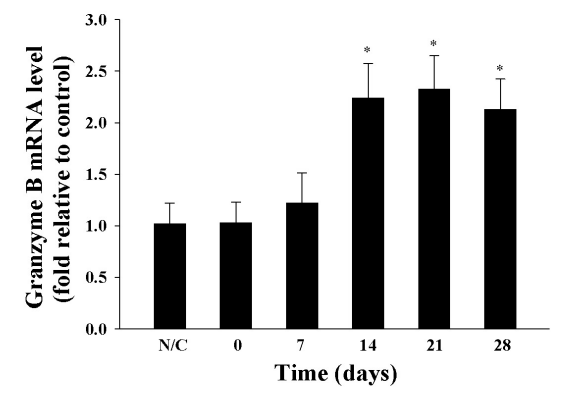

Fig. 3. The expression of perforin, granzyme $\mathrm{B}$, and NKG2D mRNA in length of time. Normal control (N/C) is the cytokines-not treated cells. Before 7 days the treatment of cytokines, perforin and granzyme B mRNAs were not expressed and but 14 days later, these cells expressed perforin and granzyme B mRNA (A, B, $* p<0.01)$. Whereas, NKG2D mRNA was expressed 21 days later $\left(\mathrm{C},{ }^{*} \mathrm{p}<0.01\right)$. Interestingly, perforin, granzyme $\mathrm{B}$, and NKG2D mRNAs were not expressed within a week (A $\sim \mathrm{C}, \quad \mathrm{p}>0.05)$. All expression is presented as the fold relative to the N/C. Results are representative of five independent experiments.

cells when stromal cells was not used as a feeder cells (data not shown), suggesting stromal cells is necessary for the development of NK cells in porcine.

\section{Analysis of perforin, granzyme $B$, and NKG2D mRNA expression by RT-PCR}

The cytokines-induced $\mathrm{CD} 2{ }^{+} \mathrm{CD} 8^{+} \mathrm{NK}$ cells were examined for the perforin, granzyme B, and NKG2D gene expression by RT-PCR. The c-kit ${ }^{+}$BM cells not pretreated with cytokines were also examined for the same genes. Fig. 3 shows that the cytokines-stimulated c-kit ${ }^{+} \mathrm{BM}$ cells have a stronger perforin, granzyme $\mathrm{B}$, and NKG2D mRNA expression than the c-kit ${ }^{+} \mathrm{BM}$ cells not pretreated with cytokines in length of time. As shown Fig. 3, perforin, granzyme $\mathrm{B}$, and NKG2D mRNA level were increased for $7^{\text {th }}, 14^{\text {th }}$, $21^{\text {th }}$, and $28^{\text {th }}$ days compare to day 0 (just before the treatment of cytokines). The perforin and granzyme B mRNA levels have more than about 2-fold 14 days later (Fig. 3A and $\left.3 \mathrm{~B},{ }^{*} \mathrm{p}<0.01\right)$. NKG2D mRNA expression was increased about 1.5-fold 21 days later compare to day 0 (Fig. $\left.3 \mathrm{C},{ }^{*} \mathrm{p}<0.01\right)$.

\section{Measurement of perforin, granzyme B, and NKG2D protein levels}

Because cytokines may induce NK cell cytotoxicity against cancer cells through a secretion of perforin [32], granzyme B [33], and NKG2D [34] in human or porcine, we examined whether the treatment of cytokines increased perforin, granzyme $\mathrm{B}$, and NKG2D activity using western blotting and fluorescence image. Cytokines-stimulated c-kit ${ }^{+} \mathrm{BM}$ cells were examined for the perforin, granzyme B, and NKG2D protein levels. The c-kit ${ }^{+} \mathrm{BM}$ cells not pretreated with cytokines were also examined for these protein levels in length of time. Fig. 4 shows that cytokines-stimulated

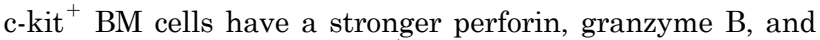
NKG2D band than the c-kit ${ }^{+} \mathrm{BM}$ cells not pretreated with cytokines in length of time for 28 days. Fig. 4 shows that the cytokines-stimulated c-kit ${ }^{+} \mathrm{BM}$ cells have increased perforin, granzyme B, and FasL levels than the c-kit ${ }^{+} \mathrm{BM}$ cells not pretreated with cytokines in length of time. As shown Fig. 4A and 4B, perforin and granzyme B levels were significantly increased 14 days later treatment of cytokines $\left({ }^{*} \mathrm{p}<0.01\right)$. Whereas, NKG2D protein was significantly increased 21 days later treatment of cytokines (Fig. $4 \mathrm{C} ;{ }^{*} \mathrm{p}<$ $0.01)$.

\section{Cytotoxic activities of cytokines-stimulated NK cells}

The in vitro cytotoxic property of effector cells (cytokinesinduced $\mathrm{CD} 2{ }^{+} \mathrm{CD} 8{ }^{+} \mathrm{NK}$ cells) against target cells (K562 cells) was analyzed. The ratios of effector cells and target cells were $100: 1$. Cytokines-induced $\mathrm{CD} 2{ }^{+} \mathrm{CD} 8^{+} \mathrm{NK}$ cells evoked a cytotoxic activity against target cells two weeks later. Cytotoxic activity induced by cytokines was seen in each time-point after cytokines treatment (Fig. 5); 1.28 $0.87 \%$ (without cytokines) and $1.53 \pm 0.52 \%$ (with cytokines) at day $0,1.32 \pm 0.76 \%$ (without cytokines) and $2.84 \pm 0.98 \%$ (with cytokines) at 7 day, $1.07 \pm 0.98 \%$ (without cytokines) and $7.65 \pm 2.27 \%$ (with cytokines) at day $14,1.52 \pm 0.85 \%$ (without cytokines) and $22.76 \pm 4.75 \%$ (with cytokines) at day 21 , and $1.98 \pm 0.91 \%$ (without cytokines) and $19.53 \pm$ $4.98 \%$ (with cytokines) at day 28 (Fig. 5 ; ${ }^{*}$ p $<0.01$ ). A significant increase in cytotoxic activity in response to treatment of cytokines was observed 14 days later treatment of cytokines. The early (before 14 days treatment of cytokines) cytotoxic changes were not significantly difference $(p>0.05)$. These results show that cytokines-induced CD2 ${ }^{+}$ $\mathrm{CD}^{+}{ }^{+} \mathrm{NK}$ cells could be more cytotoxic activities against target cells than the c-kit ${ }^{+} \mathrm{BM}$ cells not pretreated with cytokines. 
A.

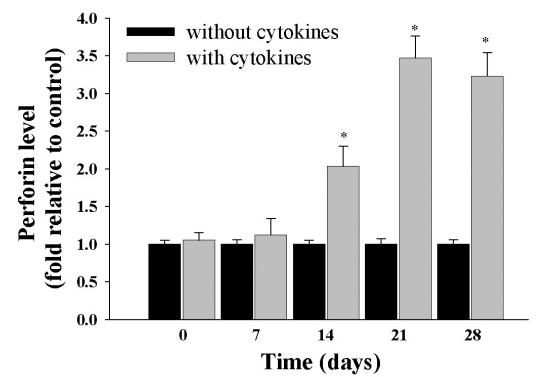

B.

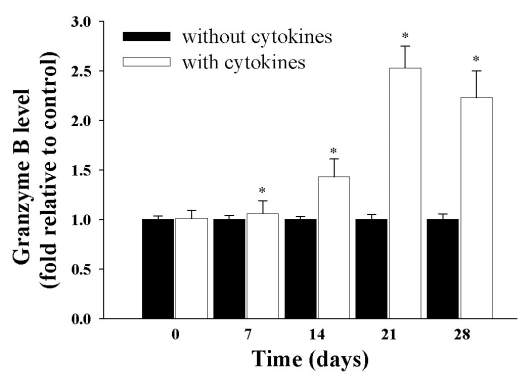

Fig. 4. The analysis of perforin, granzyme B, and NKG2D protein in length of time. The expressions of perforin, granxyme $\mathrm{B}$, and NKG2D proteins were determined by Western blotting. Densitometric analysis of each protein is shown. Within a week after the treatment of cytokines, perforin and granzyme B proteins were not expressed but two weeks later, these cells expressed perforin and granzyme B mRNAs (A, B, *p $<$ 0.01). Whereas, NKG2D mRNA was significantly expressed 21 days later treatment of cytokines $\left(\mathrm{C},{ }^{*} \mathrm{p}<0.01\right)$. All expression is presented as the fold relative to the N/C. Results are representative of five independent experiments.

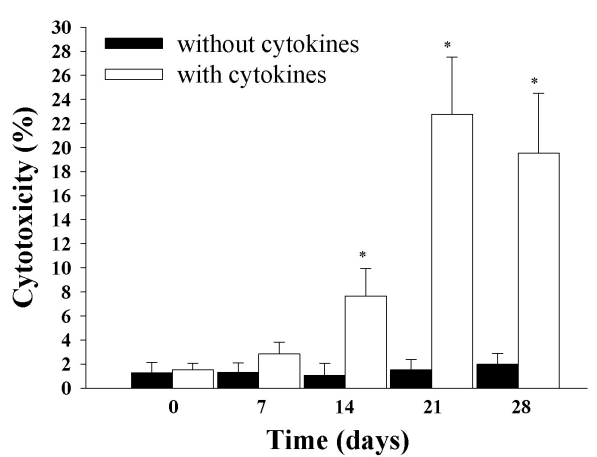

Fig. 5. Cytotoxic activity of $\mathrm{CD} 2^{+} \mathrm{CD} 8^{+} \mathrm{NK}$ cells compared with normal control. Cytokines-activated porcine $\mathrm{CD} 2{ }^{+} \mathrm{CD} 8^{+} \mathrm{NK}$ cells were incubated with K562 cells as target in a ratio of $100: 1$ for $4 \mathrm{~h}$. Cytotoxicity was measured by ${ }^{51} \mathrm{Cr}$ release assay for $18 \mathrm{~h}$. Mean cytotoxicity percent of K562 cells are shown (sample number $=5$, $* \mathrm{p}<0.01)$

\section{DISCUSSION}

NK cells are the lymphocytes that mature in the bone marrow, derived from HSC [35]. These NK cells mediate critical functions in innate immunity by directly destroying infected or transformed cells [15]. The factors regulating NK differentiation are poorly understood. However, it is certain that it involves cell to cell interactions that render NK responsive to soluble factors from the microenvironment, and several factors such as IL-15 are reported to be involved in differentiation of NK cells. Although the intact BM microenvironment is essential for NK differentiation, the stromal cells requirements might be replaced, at least partially, by early-acting cytokines including SCF, FLT3L, and IL-7 [16,17]. These cytokines were reported to induce
CD122 responsiveness through their receptors in NK cells [15]. Interestingly, despite that IL-15 has been known to be essential for NK generation [36,37], transition from HSC to premature NK does not require IL-15 [38]. Thus the generation of premature NK is regarded as IL-15-independent mechanism. Once committed to the NK lineage, premature NK cells acquire the phenotypic and functional characteristics of mature NK cells by IL-15 stimulation through their receptors. In human, IL-2 can also promote the acquisition of CD19 and KIRs on premature NK or immature NK cells [39], although IL-2 deficient mice exhibit normal population of NK cells, suggesting IL-2 is not necessary for the development of NK cells in mice. Also, in previous reports, it is observed that combination of stromal cells and HDCs may greatly increase the in vitro NK-cell differentiation from CD $34^{+} \mathrm{CD} 38^{-1+}$ cells in the presence of appropriate cytokines $[10,35,40]$. Although much is known about the function of NK cells in humans and mice, NK cells activity in swine remains preliminary, and their role in animal viral diseases still is obscure. The recent progress in these animal species has been reviewed by Boysen and Storset [41] and Gerner et al. [42]. In porcine, NK cells may account for a total of 5 to $10 \%$ of circulating lymphocytes and currently are identified as belonging to a subset of cells that coexpress CD2 and CD8 molecules [32]. Although mRNAs related to many cytotoxic molecules have been detected, until now no studies have been conducted to define their role in the generic function of porcine NK cells. But it is known that porcine NK cells can secret perforin, granzyme B and NKG2D, and kill in vitro targets [31-33]. Their function can be modulated by direct stimulation with cytokines such as interleukin-2 (IL-2), IL-12, IL-15, IL-18 [43,44]. Against this background, we selected 6 cytokines (IL-2, IL-7, IL-15, IL-21, SCF, and FLT3L), HDCs, and stromal cells as candidates for factors that induce differentiation of porcine HSCs, based on our hypothesis that such factors also play pivotal roles in the differentiation from porcine HSCs to 
NK cells. As a results, in present study, we show that a fraction of porcine c-kit ${ }^{+} \mathrm{BM}$ cells can develop into CD2 ${ }^{+}$ $\mathrm{CD}^{+}$NK cells under the influence of cytokines (IL-2, IL-7, IL-15, IL-21, SCF, and FLT3L), HDCs, and stromal cells. But, there are several other possibilities for the low frequency of CD2 and CD8 molecules, porcine NK cell markers. First, the levels of cytokines required for generation of NK cells from BM cells may have narrow ranges. Second, only a small portion of porcine c-kit ${ }^{+}$BM cells despite the right levels of cytokines can acquire NK cell properties. Consistent with this idea, $\mathrm{CD} 2^{+} \mathrm{CD} 8^{+} \mathrm{NK}$ cells differentiated from c-kit ${ }^{+} \mathrm{BM}$ cells were a mere about $35.5 \%$ (Fig. 2). But, these cytokines-induced $\mathrm{CD} 2{ }^{+} \mathrm{CD} 8^{+}$ NK cells expressed the perforin, granzyme B, and NKG2D mRNA when mRNA levels were analyzed. And, their protein levels were increased more than those in c-kit ${ }^{+} \mathrm{BM}$ cells not pretreated with cytokines (Fig. 3 and Fig. 4), suggesting that the cytokines-induced $\mathrm{CD} 2^{+} \mathrm{CD} 8^{+} \mathrm{NK}$ cells possess a mechanisms that express the factors related to NK properties. Therefore, we speculate that these cytokines are required in the stage of NK cells generation from porcine c-kit ${ }^{+} \mathrm{BM}$ cells. Another unsolved question is whether these cytokines we identified play roles completely in differentiation from c-kit ${ }^{+} \mathrm{BM}$ cells to $\mathrm{CD} 2{ }^{+} \mathrm{CD} 8^{+} \mathrm{NK}$ cells. Because some cytokines may be released from NK cells during the differentiation, we can also assume that these differentiation are partly involved in the machinery regulated by the earlier differentiated NK cells. Therefore, this study provides the first in vitro evidence of a possible role for a various of cytokines in $\mathrm{CD} 2^{+} \mathrm{CD} 8^{+}$NK cells development from porcine c-kit ${ }^{+} \mathrm{BM}$ cells. Additionally, in previous study, Sotiriadis et al. described the pig model, specifically germ-free pigs and specific pathogen-free (SPF) mini-pigs, had been used to study various aspects of the immune system, specifically innate immunity [22]. Specifically, it is reported that at least for the first 4 weeks of life, pigs are immunocompetent, owing to complete absence of foreign antigen exposure and subsequent lack of immunoglobulin production [45]. Furthermore, it is known that the porcine molecules are much more similar to those in humans [46]. This allows for study of therapeutic applications in an organism without any xenoreactivity with $\mathrm{ADCC}$ or direct cell lysis as well as graft-vs-host disease. Also, this confers a much more immediate pertinence to the use of pigs without immune rejection in human disease. But, although xenograft rejection has been largely resolved, other problems may remain major hurdles. Therefore, we think that the ideal solution to xenograft rejection is development of xenograft specific tolerance. In summary, generation of CD2 ${ }^{+}$ $\mathrm{CD}^{+} \mathrm{NK}$ cells from porcine c-kit ${ }^{+} \mathrm{BM}$ cells may present a particularly useful system for destroying malignant cells, not only in the field of veterinary medicine, but also for immunology in general.

\section{ACKNOWLEDGEMENTS}

This research was supported by Basic Science Research Program through the National Research Foundation of Korea (NRF) funded by the Ministry of Education, Science and Technology (2009-0074590).

\section{REFERENCES}

1. Sachs DH. The pig as a potential xenograft donor. Vet Immunol Immunopathol. 1994;43:185-191.

2. Cooper DK, Gollackner B, Sachs DH. Will the pig solve the transplantation backlog? Annu Rev Med. 2002;53:133-147.

3. de Vries-van der Zwan A, van der Pol MA, Besseling AC, de Waal LP, Boog CJ. Haematopoietic stem cells can induce specific skin graft acceptance across full MHC barriers. Bone Marrow Transplant. 1998;22:91-98.

4. Abe M, Qi J, Sykes M, Yang YG. Mixed chimerism induces donor-specific T-cell tolerance across a highly disparate xenogeneic barrier. Blood. 2002;99:3823-3829.

5. Kawashima I, Zanjani ED, Almaida-Porada G, Flake AW, Zeng H, Ogawa M. CD34+ human marrow cells that express low levels of Kit protein are enriched for long-term marrow-engrafting cells. Blood. 1996;87:4136-4142.

6. Dalakas E, Newsome PN, Harrison DJ, Plevris JN. Hematopoietic stem cell trafficking in liver injury. FASEB J. 2005;19: 1225-1231.

7. Ortaldo JR, Herberman RB. Heterogeneity of natural killer cells. Annu Rev Immunol. 1984;2:359-394.

8. Kondo M, Weissman IL, Akashi K. Identification of clonogenic common lymphoid progenitors in mouse bone marrow. Cell. 1997;91:661-672.

9. Coluci F, Caligiuri MA, Di Santo JP. What does it take to make a natural killer? Nat Rev Immunol. 2003;3:413-425.

10. Perez SA, Sotiropoulou PA, Gkika DG, Mahaira LG, Niarchos DK, Gritzapis AD, Kavalakis YG, Antsaklis AI, Baxevanis CN, Papamichail M. A novel myeloid-like NK cell progenitor in human umbilical cord blood. Blood. 2003;101:3444-3450.

11. Márquez C, Trigueros C, Franco JM, Ramiro AR, Carrasco YR, López-Botet M, Toribio ML. Identification of a common developmental pathway for thymic natural killer cells and dendritic cells. Blood. 1998;91:2760-2771.

12. Lotzová E, Savary CA. Human natural killer cell development from bone marrow progenitors: analysis of phenotype, cytotoxicity and growth. Nat Immun. 1993;12:209-217.

13. Miller JS, Alley KA, McGlave P. Differentiation of natural killer (NK) cells from human primitive marrow progenitors in a stroma-based long-term culture system: identification of a CD34+7+ NK progenitor. Blood. 1994;83:2594-2601.

14. Yu H, Fehniger TA, Fuchshuber P, Thiel KS, Vivier E, Carson WE, Caligiuri MA. Flt3 ligand promotes the generation of a distinct CD34(+) human natural killer cell progenitor that responds to interleukin-15. Blood. 1998;92:3647-3657.

15. Yoon SR, Chung JW, Choi I. Development of natural killer cells from hematopoietic stem cells. Mol Cells. 2007;24:1-8.

16. Mrózek E, Anderson P, Caligiuri MA. Role of interleukin-15 in the development of human CD56+ natural killer cells from CD34+ hematopoietic progenitor cells. Blood. 1996;87:26322640 .

17. Williams NS, Klem J, Puzanov IJ, Sivakumar PV, Bennett M, Kumar V. Differentiation of NK1.1+, Ly49+ NK cells from flt3+ multipotent marrow progenitor cells. J Immunol. 1999;163: 2648-2656.

18. Whiteside TL, Vujanovic NL, Herberman RB. Natural killer cells and tumor therapy. Curr Top Microbiol Immunol. 1998; 230:221-244

19. Grzywacz B, Kataria N, Kataria N, Blazar BR, Miller JS, Verneris MR. Natural killer-cell differentiation by myeloid progenitors. Blood. 2011;117:3548-3558.

20. Smyth MJ, Thia KY, Cretney E, Kelly JM, Snook MB, Forbes CA, Scalzo AA. Perforin is a major contributor to NK cell control of tumor metastasis. J Immunol. 1999;162:6658-6662.

21. Pintaric M, Gerner W, Saalmüller A. Synergistic effects of IL-2, IL-12 and IL-18 on cytolytic activity, perforin expression and IFN-gamma production of porcine natural killer cells. Vet Immunol Immunopathol. 2008;121:68-82.

22. Sotiriadis J, Shin SC, Yim D, Sieber D, Kim YB. ThomsenFriedenreich $(\mathrm{T})$ antigen expression increases sensitivity of natural killer cell lysis of cancer cells. Int $J$ Cancer. 
2004;111:388-397.

23. Layton DS, Strom AD, O'Neil TE, Broadway MM, Stephenson GL, Morris KR, Muralitharan M, Sandrin MS, Ierino FL, Bean AG. Development of an anti-porcine CD34 monoclonal antibody that identifies hematopoietic stem cells. Exp Hematol. 2007;35: 171-178.

24. Le Guern AC, Giovino MA, Abe M, Theodore PR, Qi J, Down JD, Sachs DH, Sykes M, Yang YG. Stem cell activity of porcine c-kit $^{+}$hematopoietic cells. Exp Hematol. 2003;31:833-840.

25. Grzywacz B, Kataria N, Sikora M, Oostendorp RA, Dzierzak EA, Blazar BR, Miller JS, Verneris MR. Coordinated acquisition of inhibitory and activating receptors and functional properties by developing human natural killer cells. Blood. 2006;108:38243833.

26. Shen T, Lee JH, Park MH, Lee YG, Rho HS, Kwak YS, Rhee MH, Park YC, Cho JY. Ginsenoside $\mathrm{Rp}_{1}$, a Ginsenoside derivative, blocks promoter activation of iNOS and COX-2 genes by suppression of an IKKb-mediated NF-kB pathway in HEK293 Cells. J Ginseng Res. 2011;35:200-208.

27. Yim D, Jie HB, Sotiriadis J, Kim YS, Kim KS, Rothschild MF, Lanier LL, Kim YB. Molecular cloning and characterization of pig immunoreceptor DAP10 and NKG2D. Immunogenetics. 2001;53:243-249.

28. Seo EY, Kim WK. Red Ginseng extract reduced metastasis of colon cancer cells in vitro and in vivo. J Ginseng Res. 2011; 35:315-324.

29. Yoo DS, Rho HS, Lee YG, Yeom MH, Kim DH, Lee SJ, Hong SY, Lee JH, Cho JY. Ginsenoside F1 modulates cellular responses of skin melanoma cells. J Ginseng Res. 2011;35: 86-91.

30. Wrona D, Sukiennik L, Jurkowski MK, Jurkowlaniec E, Glac W, Tokarski J. Effects of amphetamine on NK-related cytotoxicity in rats differing in locomotor reactivity and social position. Brain Behav Immun. 2005;19:69-77.

31. Toka FN, Nfon CK, Dawson H, Estes DM, Golde WT. Activation of porcine natural killer cells and lysis of foot-and-mouth disease virus infected cells. J Interferon Cytokine Res. 2009;29: 179-192.

32. Denyer MS, Wileman TE, Stirling CM, Zuber B, Takamatsu HH. Perforin expression can define CD8 positive lymphocyte subsets in pigs allowing phenotypic and functional analysis of natural killer, cytotoxic T, natural killer T and MHC un-restricted cytotoxic T-cells. Vet Immunol Immunopathol. 2006;110: 279-292.

33. Zhang B, Zhang J, Tian Z. Comparison in the effects of IL-2, IL-12, IL-15 and IFNalpha on gene regulation of granzymes of human NK cell line NK-92. Int Immunopharmacol. 2008;8:
989-996.

34. Kang SG, Jeun SS, Lim JY, Yoo DS, Huh PW, Cho KS, Kim DS, Shin HJ, Kim JH, Kim MC, Kang JK. Cytotoxicity of rat marrow stromal cells against malignant glioma cells. Childs Nerv Syst. 2005;21:528-538.

35. Freud AG, Caligiuri MA. Human natural killer cell development. Immunol Rev. 2006;214:56-72.

36. Budagian V, Bulanova E, Paus R, Bulfone-Paus S. IL-15/IL-15 receptor biology: a guided tour through an expanding universe. Cytokine Growth Factor Rev. 2006;17:259-280.

37. Carson WE, Giri JG, Lindemann MJ, Linett ML, Ahdieh M, Paxton R, Anderson D, Eisenmann J, Grabstein K, Caligiuri MA. Interleukin (IL) 15 is a novel cytokine that activates human natural killer cells via components of the IL-2 receptor. J Exp Med. 1994;180:1395-1403.

38. Vosshenrich CA, Ranson T, Samson SI, Corcuff E, Colucci F, Rosmaraki EE, Di Santo JP. Roles for common cytokine receptor gamma-chain-dependent cytokines in the generation, differentiation, and maturation of $\mathrm{NK}$ cell precursors and peripheral NK cells in vivo. J Immunol. 2005;174:1213-1221.

39. Ferlazzo G, Thomas D, Lin SL, Goodman K, Morandi B, Muller WA, Moretta A, Münz C. The abundant NK cells in human secondary lymphoid tissues require activation to express killer cell Ig-like receptors and become cytolytic. J Immunol. 2004; 172:1455-1462.

40. Briard D, Brouty-Boyé D, Azzarone B, Jasmin C. Fibroblasts from human spleen regulate NK cell differentiation from blood CD34(+) progenitors via cell surface IL-15. J Immunol. 2002; 168:4326-4332.

41. Boysen P, Storset AK. Bovine natural killer cells. Vet Immunol Immunopathol. 2009;130:163-177.

42. Gerner W, Käser T, Saalmüller A. Porcine T lymphocytes and NK cells--an update. Dev Comp Immunol. 2009;33:310-320.

43. Toka FN, Nfon CK, Dawson H, Estes DM, Golde WT. Activation of porcine natural killer cells and lysis of foot-and-mouth disease virus infected cells. J Interferon Cytokine Res. 2009;29: 179-192.

44. Pintaric M, Gerner W, Saalmüller A. Synergistic effects of IL-2, IL-12 and IL-18 on cytolytic activity, perforin expression and IFN-gamma production of porcine natural killer cells. Vet Immunol Immunopathol. 2008;121:68-82.

45. Setcavage TM, Kim YB. Variability of the immunological state of germfree colostrum-deprived Minnesota miniature piglets. Infect Immun. 1976;13:600-607.

46. Yim D, Jie HB, Lanier LL, Kim YB. Molecular cloning, gene structure, and expression pattern of pig immunoreceptor DAP12. Immunogenetics. 2000;51:436-442. 